ZalǫcZnilf

DOI 10.21697/zk.2020.7.17

\title{
SCENICZNOŚĆ FOTOGRAFII. SPEKTAKL ALBUM KARLA HÖCKERA TEATRU TRANS-ATLANTYK JAKO TEATRALNA ADAPTACJA KOLEKCJI ZDJĘĆ
}

Magdalena SzCZypiorska-ChrZanowska

\author{
Instytut Badań Literackich PAN \\ Institute of Literary Research, \\ Polish Academy of Sciences in Warsaw \\ magdalena.szczypiorska@ibl.waw.pl \\ ORCID: 0000-0002-9847-3185
}

Między 15 maja a 8 lipca wywieziono 437402 Żydów. Większość z nich pojechała do Auschwitz. Użyto do tego 447 pociagów, w ciagu 54 dni. Codziennie do Auschwitz przyjeżḋało średnio 8 tysięcy ludzi. 80 procent zabijano zaraz po przybyciu ${ }^{1}$.

Teraz musimy spojrzeć na zabójców w sposób, w jaki nie chcemy tego robić .

\section{„KAŻDY FOTOGRAF WIĘC JEST REŻYSEREM, BOGIEM JEDNEJ CHWILI, ZAŚ ZDJĘCIE - FORMĄ TEATRALIZACJI" 3}

Czy fotografia jest „sceniczna”? Jak przełożyć narrację albumu fotograficznego na narrację teatralną, język fotografii na język teatru? Na jakich poziomach fotografia i teatr spotykają się w konstrukcji scenicznej adaptacji? Jak działa pośredniczący mechanizm fotograficznego medium? I wreszcie jak medium teatru przetwarza „rzeczywistość” fotografii? Do stawiania

1 Wypowiedź Michaela Berenbauma, dyrektora Sigi Ziering Institute, z filmu Scrapbook from Hell: The Auschwitz Albums, reż. E. Nelson, prod. Creative Differences Productions Inc. for National Geographic Channel, 2008, tekst tłum. i oprac. M. Fijałkowska.

2 Wypowiedź Sary J. Bloomfield, dyrektor United States Holocaust Memorial Museum, z filmu Scrapbook from Hell...

3 F. Soulages, Estetyka fotografii. Strata i zysk, tłum. B. Mytych-Forajter, W. Forajter, Kraków 2007, s. 83. 
takich i innych pytań o relacje fotografii i teatru prowokuje sceniczna adaptacja zbioru zdjęć w spektaklu Album Karla Höckera Paula Bargetto i Teatru Trans-Atlantyk ${ }^{4}$.

Album Karla Höckera, fotograficzna materia teatralnego spektaklu, to kolekcja 116 zdjęć wykonanych od czerwca do grudnia 1944 roku w Solahütte ${ }^{5}$, a dokładniej - w Aussenkommando SS-Sola Hütte, ośrodku wypoczynkowym w Międzybrodziu Bialskim, zbudowanym dla esesmanów z Auschwitz, którzy spędzali tam kilkudniowe urlopy i krótkie wakacje. Zdjęcia z albumu Karla Höckera ujawnione zostały dopiero w 2007 roku i trafiły do Amerykańskiego Muzeum Holocaustu. Rebecca Erbelding (United States Holocaust Memorial Museum) opowiada: „Człowiek, który wysłał album i chciał pozostać anonimowy, był po wojnie oficerem amerykańskiego kontrwywiadu. Otrzymał [...] zadanie sprawdzenia obozów jenieckich i zbadania, kto był przestępcą, a kto nie. Pojechał do Frankfurtu, gdzie znalazł się w zbombardowanym budynku. Tam odkrył porzucone mieszkanie, a w szafie - ten album”. Anne Marigza (United States Holocaust Memorial Museum) podkreśla: „Album był w szesnastu kawałkach. Kolejność zdjęć nie była przypadkowa. Na każdej stronie był tytuł oraz ręcznie robione podpisy" ${ }^{\text {. }}$ Album jest pierwszą upublicznioną dokumentacją tego miejsca, jego charakteru, pejzażu i sposobów spędzania wolnego czasu przez wypoczywających tam esesmanów. Zbiór zdjęć nazwano „albumem Karla Höckera”, ponieważ SS-Obersturmführer Höcker, od maja 1944 roku adiutant komendanta KL Auschwitz Richarda Baera, częściej niż inni esesmani pojawia się na zdjęciach i jako jedyny występuje w indywidualnych, portretowych ujęciach. O tym, że właścicielem albumu był Höcker, świadczyć może także

4 Album Karla Höckera, reż. P. Bargetto, dramaturgia: M. Sikorska-Miszczuk, kostiumy: A. Kaczyńska, występują: H. Chorzelska / J. Trembecka, M. Król, K. Polkowski, G. Sierzputowski, T. Sobczak, prod. A. Balcerzak / M. Cienkowska; Teatr Trans-Atlantyk; data premiery: 21.01.2015, Instytut Teatralny im. Zbigniewa Raszyńskiego. Bardzo dziękuję Marcie Król i Paulowi Bargetto za udostępnienie nagrania spektaklu. Wszystkie cytaty w artykule podaję za tym źródłem.

5 Więcej o historii albumu oraz jego fotograficznych i etycznych kontekstach pisałam w: „Gdyby to był tylko głos nieba i chmur”. O (nie)banalności tła. Z fotograficznego albumu Karla Höckera, „Narracje o Zagładzie” 2016, nr 2.

6 Obie przytoczone wypowiedzi pochodzą z filmu Scrapbook from Hell... 
podpis z pierwszej strony: „Z komendantem SS Stubaf. Baerem, Auschwitz, 21.6.44"7.

Karl Höcker, prawdopodobnie właściciel i autor albumu, od 1933 roku był członkiem SS, od 1937 roku należał do NSDAP. Kiedy pracował w Auschwitz jako adiutant komendanta Baera, miał już za sobą cztery lata służby w obozach Neuengamme, Arbeitsdorf i na Majdanku. Kiedy kompletował swój album w Auschwitz, kiedy bywał w Solahütte, kiedy w komorach gazowych ginęły tysiące kobiet, mężczyzn, dziewczynek i chłopców, Karl Höcker był już ojcem dwojga kilkuletnich dzieci. Pod koniec wojny ujęto go ze sfałszowanymi dokumentami, na podstawie których został zwolniony. Wrócił do pracy w banku. W drugim procesie oświęcimskim, w 1965 roku, skazany został skazany na siedem lat więzienia, wyszedł na wolność po pięciu. W 1989 roku skazano go powtórnie - na cztery lata. Zmarł w 2000 roku, w wieku 89 lat.

Na zdjęciach w albumie obok Höckera występują: Rudolf Höss, Josef Mengele, Josef Kramer, Fritz Klein, Oswald Pohl, Walter Schmidetzki i inni hitlerowscy zbrodniarze, którzy bawią się i relaksują po pracy, żartują, flirtują z kobietami, urządzają pikniki, polowania i wycieczki. Trzydzieści kilometrów dalej trwa piekło Auschwitz.

$\mathrm{Na}$ innych zdjęciach z albumu oglądamy: psa Höckera, odpoczynek na tarasie, Höckera na wycieczce do kopalni, podwieczorki, Höckera na moście z kobietami z SS Helferinnen, bankiet po akcji Höss (akcji masowej zagłady Żydów węgierskich), rozrywki i atrakcje, odpoczynek i relaks, nieoficjalne spotkania i oficjalne wizyty ${ }^{8}$.

7 Zob. A. Wilkinson, Picturing Auschwitz, „The New Yorker”, 17.03.2007, http://www.newyorker.com/magazine/2008/03/17/picturing-auschwitz [dostęp 29.02.2016].

8 Por. Auschwitz through the Lens of the SS: Photos of Nazi Leadership at the Camp, http://www.ushmm.org/information/exhibitions/online-features/collections-highlights/auschwitz-ssalbum [dostęp 29.02.2016]; The Album, http:// www.ushmm.org/information/exhibitions/online-features/collections-highlights/ auschwitz-ssalbum/album [dostęp 29.02.2016]; N.A. Lewis, In the Shadow of Horror. Auschwitz SS Guardian Frolic, http://isurvived.org/InTheNews/AuschwitzSSguards_floric.html [dostęp 29.02.2016]; Laughing at Auschwitz - SS Auxiliaries Poses at a Resort for Auschwitz Personnel, 1942, http://rarehistoricalphotos.com/ 
O tej szczególnej kolekcji fotografii tak mówi Michael Berenbaum, dyrektor Sigi Ziering Institute: „W tym albumie najbardziej uderza fakt, że pokazuje on, iż naziści byli zwykłymi ludźmi. Zwykłymi ludźmi, którzy robili koszmarne rzeczy. Ludźmi takimi jak ty i ja”.

Takich właśnie ludzi, w ich strasznej, niepojętej dwoistości wyprowadza z fotografii na scenę reżyser Paul Bargetto, który wraz z zespołem Teatru Trans-Atlantyk stworzył spektakl Album Karla Höckera. Ten spektakl-hybryda, oparty na rekonstrukcji i analizie zdjęć, zbudowany został na kilku poziomach relacji między zdjęciem a sceną, rzeczywistością a kreacją, grą fotografii a grą teatralną, aktorami tamtych wydarzeń a aktorami na scenie.

\section{„TEN NASZ PROCES POLEGAŁ NA ZADAWANIU WIELU PYTAŃ"}

Spektakl Album Karla Höckera jest sceniczną adaptacją kolekcji zdjęć. Fotografia jako technika utrwalająca mniej lub bardziej teatralizowane sceny wycina je z rzeczywistości i unieruchamia. Pozostawia poza kadrem chwile przed i po, ramami kadru ogranicza topografię miejsca, pozbawia ludzi, rzeczy i pejzaże kontekstu, życia, ciągłości biografii. Tnąc czas i przestrzeń na cienkie warstwy, fotografia oferuje wieczny bezruch („sztuczną wieczność"') i szeroki repertuar potencjalnych interpretacji, możliwość budowania narracji, w której punktem wyjścia jest jedno zdjęcie, kombinacja kilku zdjęć lub - jak w przypadku Albumu Karla Höckera - cała ich kolekcja.

Adaptacja albumu Karla Höckera jest wielopoziomowym procesem, którego kierunek jest - ujmując rzecz w pewnym uproszczeniu - odwrotny do procesu fotograficznego utrwalania rzeczywistości. Bargetto i jego aktorzy rozmontowują fotografię, rozbijają jej bezruch i milczącą grozę, na oczach widzów lepią kontekst: kolory, zapachy, emocje - ciepło, zimno, rozpacz, gniew, strach, wątpliwości, nadzieję, miłość. Uruchamiają zdjęcia i oddają głos ich bohaterom.

Analiza i interpretacja fotografii była tu nie tylko twórczą pracą poprzedzającą sceniczną adaptację albumu. Sama koncepcja adaptacji zakłada

laughing-auschwitz-ss-auxiliaries-poses-resort-auschwitz-personnel-1942/ [dostęp 29.02.2016].

9 W. Szymborska, Znieruchomienie, [w:] eadem, Wiersze wybrane, wybór i układ autorki, Kraków 2000, s. 188. 
bowiem formułę procesu, poszukiwania, dociekania, zadawania pytań. Proces ten dzieje się niejako na oczach widzów. Z etapu przygotowań płynnie przechodzi do samej konstrukcji spektaklu, wnika w jego strukturę i narrację.

W prologu Paul Bargetto, reżyser i moderator spektaklu, mówi:

Dzień dobry, nazywam się Paul Bargetto i jestem amerykańskim reżyserem teatralnym. Chciałbym w kilku słowach opowiedzieć państwu o naszym projekcie. Jest to badanie albumu $\mathrm{z}$ fotografiami należącego do niemieckiego żołnierza Karla Höckera. Karl Höcker był adiutantem w Auschwitz w '44 roku. Proces naszych poszukiwań opiera się na dogłębnym studiowaniu tych fotografii, używaniu technik teatralnych, improwizacji, pracy z dramaturgiem (Małgorzata Sikorska-Miszczuk), czytaniu tekstów źródłowych i pobycie w Auschwitz. Ten nasz proces polegał na zadawaniu wielu pytań. Chcielibyśmy ten proces kontynuować z państwem teraz.

Procesualny charakter spektaklu, stworzonego raz i stwarzającego się wciąż na nowo w każdej scenie, dialogu i geście, współbrzmi z koncepcją pracy aktorów, opartą na współistnieniu i przenikaniu się trzech poziomów gry. Po pierwsze, aktorzy grają samych siebie (osoby prywatne z własną biografią, życiem rodzinnym i zawodowym, światopoglądem, cechami osobowości), po drugie - grają aktorów w trakcie prób do przedstawienia, wchodzących w dialog z reżyserem, i po trzecie wreszcie - wcielają się w bohaterów zdjęć z albumu Karla Höckera.

Płynne przechodzenie z poziomu na poziom, z roli w rolę, z intymnej prywatności w postać doktora Mengelego to ekwilibrystyka budująca ironiczno-liryczny dystans do postaci oraz rytm naprzemiennego wchodzenia w przestrzeń Auschwitz i wychodzenia z niej, pozwalająca na bezpieczne krążenie wokół pustki i niepojętej grozy fotografii z albumu Karla Höckera. Na dotknięcie i wycofanie, na bycie tam i bycie tu. Ta wyeksponowana, tocząca się na oczach widza gra między aktorem grającym siebie a aktorem grającym funkcjonariusza w piekle pozwala wyjść poza ramy fotografii, poza ramy świata Auschwitz i powiedzieć to, co nie mieściło się w tamtych ramach, kadrach, zarysach obrazów i konturach postaci. Zapytać o to, o co one nie pytały. Wykorzystać czasowy i przestrzenny dystans, by poszukać języka, słów i figur, by poszukać formuły, w której możliwe będzie pomyślenie i zarysowanie perspektywy sprawców, perspektywy zwykłych ludzi. 


\section{„SWOJĄ PRACE STARAM SIĘ ZAWSZE ZOSTAWIAĆ ZA ZAMKNIĘTYMI DRZWIAMI"}

Jaką rolę w spektaklu grupy Trans-Atlantyk grają zdjęcia z albumu Karla Höckera? Koncepcja przekładu kolekcji fotografii na spektakl teatralny włącza zdjęcia - w wielkoformatowych wersjach - w konstrukcję sceny. Fotografie $\mathrm{z}$ albumu Höckera wyświetlane są $\mathrm{w}$ tle, ale nie pełnią funkcji tła, nie są zwykłą ilustracją, nie są nawet kontekstem. Są czymś więcej współkreują przestrzeń sceny i współtworzą akcję. Każde nowo wyświetlone zdjęcie jest dla aktorów punktem wyjścia i punktem dojścia, otwiera i zamyka dzianie się, jest wąską kładką do niepojętej rzeczywistości Auschwitz i nie zawsze pasującym kluczem do wewnętrznej rzeczywistości bohaterów.

Każde nowo wyświetlone zdjęcie unieruchamia grających w spektaklu aktorów, którzy przez dłuższy lub krótszy czas naśladują pozy, gesty, miny i ustawienia modeli. Za chwilę wyłamują się z fotograficznego znieruchomienia, uruchamiają i rozwijają zastygłe na zdjęciach sceny sprzed 75 lat. Ożywiają bohaterów, budują prowizoryczny świat, w którym przez chwilę żyją esesmani z Auschwitz, aktorzy w procesie twórczej pracy i aktorzy jako osoby prywatne ze swoimi lękami, opowieściami, doświadczeniami.

Fotografie, wyświetlane na scenie zdjęcia, nie tylko prowadzą akcję spektaklu, nie tylko prowadzą aktorów, kadr po kadrze, scena po scenie, lecz także modelują sceniczną rzeczywistość: kreują scenografię, reżyserują sprzęty, przedmioty, rekwizyty i akcesoria, wśród których poruszają się aktorzy.

Spektakl jest więc grą toczącą się w rytmie wejść i wyjść, zanurzeń i wynurzeń, nieoczekiwanych zmian miejsc i zamian ról. Aktorzy wchodzą w rzeczywistość fotografii, by za chwilę wyjść z niej - już nie ci sami, bo naznaczeni tamtym światem, ale też wnoszący własny świat, pomiędzy tam i tu, wtedy i teraz. Zanurzają się w fotograficznym bycie-nie-bycie, bezpiecznie zakotwiczeni w scenie, roli, aktorskim geście. To teatralne bycie-między-światami ma różne odcienie, ale ramą dla aktorskich wędrówek wydają się dwie sceniczne sytuacje. W pierwszej - na tle wyświetlanego grupowego zdjęcia esesmanów idących w stronę fotografa - aktorzy wkładają mundury, podchodzą do ekranu, stają tyłem do publiczności, przodem do zdjęcia. Potem odwracają się i wychodzą ze zdjęcia, ze światła rzutnika w cień sceny, a później w jej światło. W sposób wyrażony wprost i starannie zademonstrowany przekraczają granice - zdjęcia i sceny, cienia i światła, 
wtedy i teraz, tam i tu. Jeden z aktorów, grający akurat Rudolfa Hössa, mówi: „Ale swoją pracę staram się zawsze zostawiać za zamkniętymi drzwiami. Nigdy mi się nie udaje. Cały czas myślę".

Druga sceniczna sytuacja, która zarysowuje ramy aktorskich eksploracji świata fotografii, czy raczej świata z fotografii, to epilog. Na ostatnim wyświetlonym zdjęciu Karl Höcker zapala światełka na choince, maszerując z kadru w kadr, metodycznie obchodzi choinkę wokół i przenosi ogień ze świeczki na świeczkę. W ostatnich scenach spektaklu aktorzy odchodzą od nakrytego białym obrusem stołu, siadają tyłem do publiczności, gaśnie światło, palą się tylko maleńkie choinkowe lampki. Z Höckerem w tle, zapalającym światełka na choince w grudniu 1944 roku - na ostatniej wojennej choince, ostatniej choince w Auschwitz - aktorzy śpiewają kolędę po niemiecku. Pochłania ich ciemność, pożera ich mrok, ale już za chwilę ich twarze widać na wyświetlanych zdjęciach. Oto historyczne zdjęcia z Auschwitz zastąpione zostały współczesnymi zdjęciami z Auschwitz, a Höss, Mengele, Höcker, Pohl, Kramer, Thuman - aktorami, którzy w ramach przygotowań do spektaklu byli w Muzeum Auschwitz-Birkenau i w okolicach Oświęcimia. Ich czarno-białe zdjęcia na tle drutów kolczastych, bramy, szyldu szpitala i innych rozpoznawalnych miejsc są drugim brzegiem ramy, w której aktorzy poruszali się między światami. W pierwszej scenie światło i cień wypychają aktorów ze świata fotografii w świat sceny. W drugiej - świat fotografii wciąga ich w swoje inscenizacje, zabiera ich tam, gdzie 75 lat temu byli tamci, gdzie pozowali do fotografii.

\section{„NIE MA MNIE NA NASTĘPNYM ZDJĘCIU”}

Aktorzy grający osoby prywatne z własnymi imionami i własną biografią, aktorzy grający próby i wreszcie aktorzy grający spektakl - te trzy poziomy płynnie przenikają się i wymieniają: sekundy dzielą scenę, w której Marta Król odmawia wykonania na polecenie reżysera gestu Heil Hitler, od sceny, w której jest kochanką Mengelego. Kiedy kończy się scena, w której Grzegorz Sierzputowski gra akurat Waltera Schmidetzkiego, i aktorzy ustawiają się pod dyktando kolejnego zdjęcia - do następnej, jeden z kolegów mówi mu: „Jesteś Hössem”. „Wiem” - odpowiada Sierzputowski i idzie w stronę krzeseł. „A teraz dokąd idziesz?” - pyta kolega. Sierzputowski/Höss odpowiada: „Nie ma mnie na następnym zdjęciu, więc postanowiłem usiąść. Ale - kontynuuje, opowiadając o Hössie jako Höss i jednocześnie jako aktor - opowiem 
państwu jedną rzecz: Rudolf, Rudolf Höss w swojej książce, właściwie spowiedzi, przed śmiercią w Auschwitz, przed powieszeniem go, wyznaje, że pochodził z bardzo religijnej rodziny".

Ta wymiana zdań z kolegą aktorem, konstatacja, że brak postaci na fotografii oznacza brak aktora na scenie, a także przejście w tryb wypowiedzi dla publiczności trafnie ujmują płynność wędrówek między poziomami gry, między rolami.

Wiele tych przejść, zmian poziomów moderuje reżyser, wydając aktorom polecenia (jak w scenie z tańcem na moście), prosząc ich o wykonanie małych etiud (jak w dwóch wariantach sceny, w której komendant Baer na dwa sposoby proponuje Höckerowi stanowisko adiutanta w Auschwitz) czy zadając pytania, na które aktorzy często odpowiadają tak, jakby tłumaczyli oczywistości przybyszowi z innego świata. Bo Paul Bargetto zachowuje się jak przybysz z innego świata: wielokrotnie dopytuje, co to jest Auschwitz, gdzie leży, co tam robią oficerowie, co znaczy salut Heil Hitler. Wrażenie odrębności postaci reżysera wzmacnia odrębność języka. Aktorzy grają po polsku z niemieckimi wstawkami wtedy, gdy czytają podpisy na wyświetlanych fotografiach, zapisane równym pismem Karla Höckera, albo wtedy, gdy śpiewają kolędę lub gdy wymawiają nazwy funkcji i dystynkcji oficerów SS. Bargetto natomiast posługuje się tylko angielskim - jego wystąpienie w prologu tłumaczy na polski jedna z aktorek. Pozostałe polecenia, pytania, zwroty do aktorów nie są tłumaczone - i brzmią dziwnie obco w zderzeniu z obrazami z Auschwitz, jakby ten wycinek obozowego świata oglądał ktoś z zewnątrz, ktoś, komu trudno zrozumieć mechanizmy, niuanse, detale. Ktoś, komu trzeba wyjaśniać sprawy, które wydają się jasne i oczywiste.

Pozycja Bargetta - który w konstrukcji spektaklu zajmuje miejsce przeważnie niewidoczne, jest raczej głosem niż osobą (z wyjątkiem scen, w których fotografuje sceny upozowane na wzór zdjęć z albumu, a więc uprawia coś w rodzaju fotografii drugiego stopnia) - to pozycja moderatora ulokowanego poza centrum zdarzeń, poza sceną ze zdjęciami w tle i rządkami krzeseł z trzech stron. Nie ma go tam, w tym pierwszym rzędzie krzeseł, gdzie zwykle siadają już widzowie, a tu - aktorzy patrzący na zdjęcia. Nie ma go tam, gdzie są fotografie, i nie ma go tam, gdzie jest scena. Jego postać, jego rola i pozycja obcego, innego, przybysza operującego innym językiem, jego ulokowanie wszędzie i nigdzie, wiążą i spajają przestrzeń sceny z płaszczyzną 
fotografii, świat teatru ze światem zdjęć, dwie rzeczywistości, dwa czasy, dwa głosy, dwa milczenia.

\section{„W CIĄGU DNIA MORDOWALI DZIECI, A PO POWROCIE DO DOMU WYCHOWYWALI WŁASNE"}

Czarno-biała rzeczywistość fotografii w spektaklu Album Karla Höckera nie przekłada się na prosty, wyrazisty, czarno-biały system ocen, na pozytywowo-negatywowe myślenie o świecie i rozumienie świata.

Co jednak miałaby znaczyć pojawiająca w recenzjach spektaklu formuła: „ukazanie perspektywy sprawców”? W filmie Scrapbook from Hell: The Auschwitz Albums Michael Berenbaum wskazuje podstawowy dysonans widza, rozdzierający dysonans obserwatora niepojętej, niemożliwej do złożenia w jedną całość, rozpadającej się rzeczywistości:

Można się domyślać, że ci mężczyźni po tym, jak przez cały dzień zabijali ludzi, spędzali noc z kobietą. W ciągu dnia mordowali dzieci, a po powrocie do domu wychowywali własne. Znamy to tylko z teorii, ale sam widok facetów, którzy przez cały dzień robili coś tak strasznego, a później flirtowali, śmiali się, chodzili po lesie i żartowali, sprawia, że czujesz narastającą wściekłość.

W spektaklu nie ma wściekłości, nie ma patosu, nie ma diagnoz, nie ma wielkich pytań - są pytania maleńkie, pytania drobne jak ziarna piasku, pytania, przez które zacina się i skrzypi machina fotograficznej i teatralnej narracji. Te maleńkie pytania wplecione są często nie w tę warstwę gry, w której aktorzy grają esesmanów, ale w tę, w której grają samych siebie. W samym środku sceny, w której pada informacja, że Höss był ojcem pięciorga dzieci, a zaraz potem pozostali opowiadają o swoich dzieciach, jedna $\mathrm{z}$ aktorek, Marta, mówi nagle:

Wracam do domu po próbie, zmęczona, totalnie skonana, otwieram drzwi, a tam moim oczom ukazuje się przewrócona choinka, potłuczone szkło wszędzie, idę do łazienki, tam jest wyrwany kran, [...] cała łazienka jest w wodzie. Wszystko pływa. Idę do pokoju, a tam żyrandol zerwany i taki kikut tylko z żarówką sobie wisi [...]. No i wołam moją córeczkę i pytam ją: powiedz, kto to zrobił? A ona na to: „to nie ja”. Pytam mojego synka, kto to zrobił, powiedz mi - „to nie ja”. To wołam moją mamę i mówię, mamo, moja kochana mamo, wytłumacz mi, kto to zrobił. A ona na to: „samo się zrobiło". 
Kluczowa w tej scenie formuła „to nie ja - samo się zrobiło” wydaje się ironicznym przetworzeniem reakcji sprawców w odniesieniu do problemu winy i odpowiedzialności za nazistowskie zbrodnie. Sam Karl Höcker w końcowym oświadczeniu w procesie z 1965 roku powiedział: „Dowiedziałem się o tym, co działo się w obozie, gdy tam przebywałem. Nie miałem z tym nic wspólnego. Nie miałem żadnego wpływu na te wydarzenia. Nie chciałem ich i nie brałem w nich udziału. Nikogo nie skrzywdziłem i z mojego powodu nikt w Auschwitz nie zginął"10.

$\mathrm{W}$ innej scenie, podczas odgrywanego dialogu z publicznością, rozwija się swobodna wymiana zdań między aktorami a reżyserem, który od czasu do czasu włącza się w tok rozmowy. Na tle fotografii ze swastykami, znakami SS i heilującymi esesmanami aktorzy zastanawiają się, czy publiczność rozpoznaje i umie nazwać symbole na zdjęciu. W pewnym momencie włącza się reżyser z pytaniem: „Co to jest ten salut?”. Aktorzy informują go, że to gest pozdrowienia Heil Hitler i co on oznacza. Jedna z aktorek, Marta, podkreśla, że ten znak jest w Polsce zakazany. Aktorzy żartują, interpretując znaczenie gestu. Marta protestuje, gdy inna aktorka, Helena (Chorzelska), wyciąga rękę w hitlerowskim pozdrowieniu: „Nie pokazuj tego, nie pokazuj”.

Reżyser pyta: „Marta, możesz zademonstrować salut?”. Marta mówi: „Nie”. Aktorzy dziwią się, żartują, pytają o powody odmowy, namawiają. Marta wyjaśnia, że z zasady nie pokazuje tego znaku, a kiedy grający Höckera Krzysztof (Polkowski) argumentuje, że przecież grają w spektaklu, Marta ripostuje: „Dobrze: gramy, nie gramy, są pewne granice. Ta granica już jest dla mnie przekroczona. No to co, że gramy spektakl. To co, ja mam wszystko robić na spektaklu, tak, mam się... nie wiem, wszystko co mi reżyser powie, jak mi zagra, to mam grać?". Gdy wśród przekomarzań reżyser prosi drugą aktorkę, Helenę, o pokazanie hitlerowskiego salutu, ta zgadza się za śmiechem, komentując, że jest „prosto po szkole” i „robi, co reżyser każe”. Rozczarowana Marta stwierdza, że spodziewała się po niej czegoś więcej, a Helena bagatelizuje sprawę: „Przestań, to jest przecież... na luzie. No jedną rękę podnosisz do góry i koniec”. Napięcie między wykonaniem polecenia a odmową, między pustym, aktorsko rozumianym gestem a etycznym sensem gestu i jego kontekstem eskaluje w scenie przemocy fizycznej. Pozostali

10 Fragment oświadczenia Karla Höckera, złożonego w procesie z 1965 roku, pochodzi z filmu Scrapbook from Hell... 
aktorzy wstają i żartując, ryczą: „Heil Hitler”. Tomek (Tomasz Sobczak) wyciąga Martę na środek, szarpie ją: „No raz pokaż, no dawaj!”. Pozostali przekrzykują jej „Ale ja nie chcę”, wrzeszczą: „Raz zrób, po prostu zrób to, wyciągasz rękę i już, Marta raz!”. Tomek w tańcu próbuje wyprostować jej rękę, a kiedy aktorzy, nie słuchając jej protestów, krzyczą: „Zrób to raz. Weź jej zrób!”, przewraca Martę na podłogę i prostuje jej rękę, wrzeszcząc: „Heil Hitler". Marta zastyga i w jednej chwili, rozciągnięta na podłodze, staje się obozową funkcjonariuszką zakochaną w Mengelem, którego gra Tomek.

Ta wstrząsająca scena odmowy i zbiorowej przemocy, ten repertuar postaw i reakcji na prośbę reżysera, zbiorowy opór wobec inności, która wywołuje dyskomfort u pozostałych i demaskuje ich wewnętrzny konflikt cała ta pełna napięcia scena symbolizuje w istocie różne reakcje na rozkaz przełożonego, gotowość do powiedzenia „nie” i brak tej gotowości. Jest próbą zmierzenia się z pytaniem, dlaczego nikt się nie wyłamał, dlaczego „oni” (esesmani) robili to, co robili, dlaczego nie protestowali, dlaczego nie mówili „nie”. Pytania te, przeniesione w spektaklu z aktorów grających esesmanów na aktorów grających siebie samych, stają się pytaniami o to, dlaczego „my” nie mówimy „nie”, dlaczego „my” nie protestujemy; o to, jak zachowujemy się wobec tych, którzy mają odwagę bronić swoich racji, ale są dla nas źródłem dysonansu i wewnętrznego konfliktu. To już nie tylko pytanie o to, dlaczego „oni” nie mówili „nie”, ale także o to, dlaczego „my” mówimy „tak".

W tej scenie - ale także w scenie opisanej wcześniej, kiedy Marta opowiada o swoim powrocie do zdemolowanego domu, a na pytanie: „kto to zrobił?”, słyszy odpowiedzi: „to nie ja”, „to nie ja” i „samo się zrobiło” - w sposób szczególny powraca raz już przywołana formuła Michaela Berenbauma: „W tym albumie najbardziej uderza fakt, że pokazuje on, iż naziści byli zwykłymi ludźmi. Zwykłymi ludźmi, którzy robili koszmarne rzeczy. Ludźmi, takimi jak ty i ja”.

\section{„POJAWIAJĄ SIĘ WĄTPLIWOŚCI. I TRZEBA JE ZABIĆ”}

Refleksje, w których wprost wyrażone są wahania i wątpliwości esesmanów, w najbardziej wyrazisty sposób obecne są w dwóch scenach.

W pierwszej - na tle fotografii z domu wypoczynkowego w Solahütte, gdzie na tarasie ustawione są leżaki, na których esesmani drzemią, odpoczywają, flirtują z kobietami - siedzi Marta grająca SS-Helferin i Krzysztof 
grający Karla Höckera. Marta/SS-Helferin zwierza się Krzysztofowi/ Höckerowi, z oporami wyznając, że czasami, choć rzadko, odczuwa: „[...] nie bardzo wiem, jak to nazwać, jak to ująć. To chyba są wątpliwości”. Na pytanie Krzysztofa/Höckera, czego dotyczą jej wątpliwości, Marta/SS-Helferin najpierw mówi o braku pewności, czy przełożeni zadowoleni są z niej i z jej pracy, po chwili jednak dodaje: „Oczywiście, czasami też pojawiają się takie inne wątpliwości, wiesz, o czym mówię, czy czasem nie za daleko... No ale to bardzo rzadko, właściwie wcale, przepraszam”.

W następującej po tym zwierzeniu wymianie zdań Krzysztof/Höcker w pełnej empatii refleksji przekonuje Martę/SS-Helferin, że „wątpliwości są dobre”, że „są częścią nas”, że ktoś, kto ma wątpliwości, pracuje nad sobą, rozwija się, jest myślącym i czującym człowiekiem. Pod wpływem wypowiedzi Krzysztofa/Höckera, łagodzących jej wewnętrzny konflikt, Marta/ SS-Helferin gładko przechodzi od zastrzeżenia: „ale przecież nie powinniśmy mieć wątpliwości”, do konstatacji: „To znaczy, uważasz, że to dobrze, że mamy wątpliwości, tak?”. Krzysztof/Höcker odpowiada: „Nie wiem, nie wiem. Ale to jest część naszego człowieczeństwa”. To jeden z tych momentów spektaklu, w których przepaść między usuniętym poza kadr światem Auschwitz a rozgrywanym na scenie, $\mathrm{z}$ fotografią w tle, światem Karla Höckera i jego towarzyszy esesmanów znosi jakiekolwiek poczucie spójności, przekreśla możliwości pojmowania. Jednak już za chwilę Krzysztof/ Höcker doda: „Ale musisz pamiętać, że to, co robimy, jest dobre. Jesteśmy przecież $\dot{z} . . . "$, i wyjaśni:

Ja też mam wątpliwości. [...] Ale zawsze wtedy, kiedy pada rozkaz, to wiem, że jest ponad wszystkim. Widziałem kiedyś taką rzecz, jak zabicie cielątka. [...] Ale wytłumaczyłem to sobie wtedy tak, że musisz to robić. Musisz się czymś żywić. [...] I kiedy tej śmierci nie widzisz, to wszystko jest w porządku. Ale jak ją zobaczysz...

Marta/SS-Helferin: To wtedy...

Krzysztof/Höcker: Pojawiają się wątpliwości.

Marta/SS-Helferin i Krzysztof/Höcker (razem): I trzeba je zabić.

Końcowa konstatacja, wypowiedziana w zgodnym dwugłosie, wydaje się jednocześnie - w sposób jasny dla obydwojga - zamykać kwestię moralnych wątpliwości i otwierać pole semantycznej dwuznaczności: zabijanie 
wątpliwości i zabijanie ofiar wiąże się w tej formule w kolisty splot przyczyny i skutku.

W drugiej ujawniającej wahania i wątpliwości esesmanów scenie na tle fotografii Karla Höckera i Hansa Delmotte’a aktorzy przedstawiają kolegę: „Doktor obozowy, Hans Delmotte”. Wywiązuje się krótka dyskusja, lekka i pozornie żartobliwa, choć pełna psychologicznego i dramaturgicznego napięcia. Ta towarzyska konwersacja między aktorami a fotograficznym widmem Delmotte'a dotyczy belgijskiego lekarza SS, asystenta doktora Mengelego, który początkowo odmówił udziału w selekcjach. Wynika z niej, że Delmotte to „ten, co się tak czuje lepszy” („nie, to niemożliwe” komentuje Marta), ten smutny - „smutny Delmotte”. „Niemożliwe” staje się słowem-kluczem w tej scenie, od pierwszego komentarza Marty, która po chwili proponuje, że opowie Delmotte'owi historię „taką wesołą, ale zupełnie niemożliwą”: „wyobraź sobie, że po pierwszej selekcji kompletnie się załamujesz, mówisz, że więcej nie będziesz tego robić i wymiotujesz”. „Niemożliwe” - stwierdza Grzegorz. „Nie, nie, nie, to niemożliwe” - mówi Marta. W dalszym ciągu historii do Delmotte’a przychodzą kolejno komendant i lekarz garnizonu z radami: „Hans, weź się w garść”, odwiedza go Mengele i tłumaczy: „Delmotte, chłopie, no normalnie weź się w garść. No, co zrobisz, będziesz miał dziesięciu rannych i będziesz musiał wybrać, któremu pomożesz najpierw. No weź się w garść”. Żona błaga go na kolanach: „Hansie, musisz przywrócić sobie właściwą perspektywę”.

Ta niby-pogodna i pełna dobrodusznych rad historia, opalizująca grozą i śmiercią, w finale ujawnia swój sens w serii powtarzających się pytań, spod których przez chwilę prześwituje odpowiedź i natychmiast znika, przekreślona diagnozą „niemożliwe”.

Marta: I co robisz?

Grzegorz: No, co robisz?

Marta: W garść się bierzesz, spinasz się na całego i dajesz radę. Na całego. I co robisz?

Grzegorz: No, co robisz?

Marta: Co robisz? No powiedz, co robisz? Popełniasz samobójstwo?

Grzegorz: Niemożliwe.

Scena ukazuje napięcia między możliwym i niemożliwym, między tym, co do pomyślenia, i tym, czego pomyśleć się nie da, a przez wprowadzenie 
wartościującej formuły „właściwa perspektywa” ujawnia dwuznaczność postaw i arbitralność ocen.

Obie sceny - i rozmowa o wątpliwościach nadzorczyni SS, i niby-żartobliwa opowieść dla Delmotte’a - przez swoją pozorną lekkość, przez niemal żywą obecność tamtej rzeczywistości na wyświetlanych zdjęciach, przez pomieszanie fotografii i teatru sprawiają, że na chwilę zwalniają sprawne tryby i dobrze działające mechanizmy tamtej rzeczywistości i rzeczywistości sceny. Akcja się zacina, jak wielokrotnie ponawiane pytania: „co robisz?”, „co robisz?”, „no, co robisz?”, akcja traci energię, jak w bezradnym i bezmyślnym powtarzaniu: „wątpliwości są częścią nas”.

Nieczęste są w spektaklu sceny, w których w twardym murze pewności, spójności i przekonań, że „zawsze wtedy, kiedy pada rozkaz, to wiem, że jest ponad wszystkim”, albo że „kiedy pojawiają się wątpliwości, to trzeba je zabić", powstają drobne szczeliny, pojawia się niepewność, opór, przebłysk świadomości tego, co dzieje się wokół. Zawsze wtedy można powtórzyć za Karlem: „Może nie warto rozglądać się dokoła? Może wy, gdybyście byli na moim miejscu, to byście chcieli się rozejrzeć dokoła. A może chodzilibyście z zamkniętymi oczami”.

Między bohaterami zdjęć, między bohaterami spektaklu mocniej niż wątpliwości wybrzmiewają emocje, uczucia, w których powracają dzieciństwo, wspomnienia, odniesienia do niemieckiej literatury i muzyki, i wreszcie miłość. Miłość jednej z funkcjonariuszek do Josefa Mengelego i miłość drugiej do Karla Höckera, którego żona odmówiła przeprowadzki do Auschwitz z dwójką małych dzieci. Miłość przesłania obu kobietom wszystko lub prawie wszystko, co dzieje się dookoła, oślepia i układa elementy rzeczywistości tak, że nie widzą niczego poza własnym nieodwzajemnionym uczuciem jak w porażającej wypowiedzi kochanki Mengelego: „Czy on się o mnie troszczy? Nie. Czy pomógł mi uruchomić rower? Nie. A przecież jeżdżę na obozową pocztę z przesyłkami oczu do Berlina dla doktor Kariny Magnusen, która pracuje nad doświadczeniem nad kolorem oczu. Dość tego. Muszę się nauczyć sama sobą opiekować”. 


\section{„NALEŻY [FOTOGRAFIĘ] RACZEJ PORÓWNYWAĆ DO TEATRU I MYŚLEĆ O NIEJ JAKO O OPRACOWANEJ PRZEZ GRE”"}

Czy fotografia jest „sceniczna”, czy jest teatralna? Czym jest, czym może być „sceniczność” w przypadku sztuki, która sama opiera się na inscenizacji, na odegraniu ról, na aranżowaniu fotograficznego teatru przed okiem aparatu? Francuski fotograf Robert Doisneau mawiał o swoich zdjęciach: „Zrobiłem sobie mały teatrzyk”. Teoretyk fotografii François Soulages wiele pisał o teatralizacji jako ważnej cesze fotografii:

„To, co zostało odegrane”: wszyscy (fotografowany, fotografik i widz) myla się co do fotografii oraz mogą być zmyleni. Oglądający zdjęcie sądzi, że jest ono dowodem rzeczywistości, podczas gdy stanowi ono wyłącznie oznakę gry. Każde zdjęcie nas okłamuje. To zostało odegrane, gdyż wydarzyło się i ma miejsce gdzie indziej, niż sądzimy. Tak jak w teatrze w fotografii nie ma odniesienia, ani tam, gdzie się myśli, ani tam, gdzie się jest, ani tam, gdzie się sądzi. Odsyła ona, być może, jedynie do siebie samej"1.

Fotografia z definicji jest więc „teatralna” czy „teatralizująca”. Jak pisze Soulages: „Każdy fotograf więc jest reżyserem, Bogiem jednej chwili, zaś zdjęcie - formą teatralizacji”'12.

$\mathrm{W}$ przeniesieniu na scenę, $\mathrm{w}$ mechanizmie scenicznej adaptacji fotografia zazwyczaj wymaga zamiany bezruchu na ruch, śmierci na życie, dwuwymiarowości w trójwymiar - czyli procesu odwrotnego do tego, co dzieje się w momencie robienia zdjęcia, które unieruchamia, uśmierca, sprowadza trójwymiarową przestrzeń do dwuwymiarowej płaszczyzny. Jednak punkt wyjścia tego trójelementowego procesu (rzeczywistość - fotografia - spektakl) i punkt dojścia nie są tożsame. Reżyser-fotograf kreuje scenę przed aparatem (przed-fotograficzną rzeczywistość) tak, by była dobrym kadrem. Reżyser teatralny kreuje scenę na motywach fotografii (po-fotograficzną rzeczywistość) tak, by była dobrym fragmentem spektaklu. W tych procesach kodowania (z rzeczywistości w fotografię) i odkodowania (z fotografii w spektakl) jest istotne przesunięcie i naddatek: bez wiedzy spoza kadru, bez znajomości kontekstu, bez pogłębionej interpretacji zdjęć, bez

11 F. Soulages, op. cit., s. 81-82.

12 Ibidem, s. 83. 
skonstruowania fabuły, w której strukturę wbudowane są zdjęcia, spektakl byłby tylko mechanicznym przełożeniem scen, czymś w rodzaju sekwencji „żywych obrazów”, w których aktorzy są tylko podmiotami z niejasną tożsamością, zagubionymi w kadrze i na scenie. Tak jak grający Karla Höckera aktor, który - stojąc przed wyświetlonym zdjęciem przedstawiającym Karla bez munduru - mówi:

Stoję. Do zdjęcia pozuję. Stoję i nie wiem, gdzie jestem. Nie wiem... nie wiem, gdzie jestem w tym momencie, gdy ktoś robi mi to zdjęcie. Nie wiem, gdzie jestem, a najgorsze jest to, że nie wiem nawet, kim jestem. Ktoś na mnie patrzy, robi mi zdjęcie, widzi mnie. Może on lepiej wie, co ja tutaj robię. Dlaczego jestem tak dziwnie ubrany? Kto mi kazał włożyć te buty? Dlaczego mam takie spodnie? Dlaczego mi ręce tak zwisają, przecież... Nie pytajcie mnie o to w tej chwili. A może, może to lepiej, że ja nie wiem, kim jestem. Może nie warto rozglądać się dokoła? [...] Nie wiem. To nieistotne.

Kiedy wkłada mundur, natychmiast odzyskuje tożsamość i świadomość siebie: „Ja wiem, kim jestem, tak, wszystko do mnie wróciło. Jestem tutaj na służbie. Na stanowisku. Nazywam się Karl Höcker. Jestem adiutantem. Jest super. Mam fajnego psa". Definiuje go mundur, definiuje go kontekst.

Sceniczność rozumiana jako zdolność do bycia materią teatralnej adaptacji jest więc w przypadku fotografii dość dwuznaczna. Sama będąc kolekcją unieruchomionych scen, potrzebuje interpretacji, potrzebuje tekstu i jego kreacyjnej potencji, potrzebuje języka i głosu, który ją zdefiniuje i opowie, tak jak mundur definiuje Karla Höckera i jego narrację.

Między grą fotografii i grą teatru istnieje więc podobieństwo sztuczności zbudowane na dialektycznych relacjach rzeczywistości i pozoru, iluzji i realnego. Jak podkreśla Soulages:

Po raz kolejny umknęła nam rzeczywistość, być może po prostu dlatego, że jest niemożliwa do pokazania. Ludzie wydają się potrzebować wiary i być może dlatego pozostają w świecie pozoru. Nie mogąc przyjąć do wiadomości, że „to zostało odegrane”, zakładają, iż zdjęcie stanowi dowód „realnego”. To upodobanie do iluzji pochodzi skądinąd i nie jest szczególną cechą fotografii, ale powinno być ujawnione, by mogła ona pełnić inną rolę niż marnego świadka niemożliwej rzeczywistości. Należy ją raczej porównywać do teatru i myśleć o niej jako o opracowanej przez grę: grę ludzi i rzeczy. Wynika to $\mathrm{z}$ faktu, iż fotografię przepełnia ta gra świata/gra towarzyska. Fotografia, 
wikłając nas w grę, wprowadza w błąd i wkracza do świata sztuk. Stoi ona po stronie sztuczności, a nie realnego ${ }^{13}$.

\section{Bibliografia}

Auschwitz through the Lens of the SS: Photos of Nazi Leadership at the Camp. http://www.ushmm.org/information/exhibitions/online-features/collections -highlights/auschwitz-ssalbum.

Laughing at Auschwitz - SS Auxiliaries Poses at a Resort for Auschwitz Personnel, 1942, http://rarehistoricalphotos, com/laughing-auschwitz-ss -auxiliaries-poses-resort-auschwitz-personnel-1942/.

Neil A. Lewis, In the Shadow of Horror. Auschwitz SS Guardian Frolic, http:// isurvived.org/InTheNews/Auschwitz-SSguards_floric.html.

François Soulages, Estetyka fotografii, Strata i zysk, tłum. B. Mytych-Forajter, W. Forajter, TAiWPN Universitas, Kraków 2007.

Magdalena Szczypiorska-Chrzanowska, „Gdyby to był tylko głos nieba i chmur”. O (nie)banalności tła. Z fotograficznego albumu Karla Höckera, „Narracje o Zagładzie" 2016, nr 2.

Wisława Szymborska, Znieruchomienie, [w:] eadem, Wiersze wybrane, wybór i układ autorki, Wydawnictwo a5, Kraków 2000.

The Album, http://www.ushmm.org/information/exhibitions/online-features/ collections-highlights/auschwitz-ssalbum/album.

Alec Wilkinson, Picturing Auschwitz, „The New Yorker”, 17.03.2007. http://www. newyorker.com/magazine/2008/03/17/picturing-auschwitz.

\section{Filmografia}

Scrapbook from Hell: The Auschwitz Albums, directed by E. Nelson, prod. Creative Differences Productions Inc. for National Geographic Channel, 2008.

\section{Spektakle teatralne}

Album Karla Höckera, reż. P. Bargetto, dramaturg: M. Sikorska-Miszczuk, kostiumy: A. Kaczyńska, występują: H. Chorzelska / J. Trembecka, M. Król, K. Polkowski, G. Sierzputowski, T. Sobczak, prod. A. Balcerzak

13 Ibidem. 
/ M. Cienkowska; Teatr Trans-Atlantyk; data premiery 21.01.2015, Instytut Teatralny im. Zbigniewa Raszyńskiego [nagranie ze spektaklu].

\section{Is Photography Adaptable for a Stage? The Performance Karl Höcker's Album by the Trans-Atlantyk Theatre as a mise-en-scene of a Collection of Photographs}

Is photography 'stageable'? How to translate the narrative of a photo album to a theater stage? On what levels do photos and theater meet while constructing the stage adaptation? This paper aims at answering (these and other) questions about the relation between photo images and the theater using the example of the mise-en-scene of a collection of photos (Karl Höcker's album) in the performance Karl Höcker's Album by Paul Bargetto and the Trans-Atlantyk Theatrical Group. Karl Höcker's photo album is a collection of photos taken between June and December 1944 in Aussenkommando SS-Sola Hütte, a spa complex in Międzybrodzie Bialskie built for SS troops from Auschwitz, who used to spend their short holidays there. Paul Bargetto's performance is made on the reconstruction and analysis of photos, created on several levels of relations between the photo and the performance, between the reality and the creation, the photo play and the theater play, the actors of then and the performers of now. The article tackles these relations discussing the following issues: how to translate the language of photography into the language of theater? How does photography (de)construct theater? And finally, how does the theater medium transform the 'reality' of the photo?

Keywords: theater, photography, stage adaptation, Auschwitz, Holocaust, Karl Höcker's album 